\title{
The Role of Media in The United States Environmental Diplomacy: A Case Study of Oil- spill Disaster in Deepwater Horizon
}

\section{Verdinand Robertua, Immanuel Josua H Silitonga}

\section{Verdinand Robertua}

$\begin{array}{lll}\text { Affiliation } & : & \text { Universitas Kristen } \\ & \text { Indonesia } \\ \text { City } & : & \text { Jakarta } \\ \text { Country } \quad: & \text { Indonesia } \\ \text { Email } & : & \\ \text { Verdinand.robertua@uki.ac.id }\end{array}$

Immanuel Josua H Silitonga

$\begin{array}{lcl}\text { Affiliation } & : & \text { Universitas Kristen } \\ & \text { Indonesia } \\ \text { City } & : & \text { Jakarta } \\ \text { Country } & : & \text { Indonesia } \\ \text { Email } & : & \\ \text { Manueljhs262@gmail.com }\end{array}$

History

$\begin{array}{lll}\text { Submission } & : & \text { 25 January } 2021 \\ \text { Review } & : & \text { 14 April } 2021 \\ \text { Completed } & & \\ \text { Accepted } & : & \text { 19 April } 2021 \\ \text { Available } & : & \text { 4 June } 2021 \\ \text { Online } & & \end{array}$

DOI :

10.51413/jisea.Vol2.Iss1.2021.30-53

\section{Copyright}

This is an open access article distributed under the term of the creative commons attribution 4.0 international licence

\begin{abstract}
The Deepwater Horizon Oil-Spill is the most disastrous environmental pollution event in America's history. The film Deepwater Horizon, which takes the title exactly matches the name of the incident, explains the backgrounds of the catastrophe. This film shows that the accident occurred due to the negligence of British Petroleum as a company that manages the Deepwater Horizon rig. To reveal the role of the film in United States environmental diplomacy, the researcher will use the Deepwater Horizon film as a case study and the concept of environmental diplomacy as a unit and research analysis tool. This study uses qualitative research methods with data collection techniques, such as literature surveys and observations. This research argues that media is an essential component that plays a role in environmental diplomacy.
\end{abstract}

Key Words: Environmental Diplomacy, Deepwater Horizon, the United States, Media

\section{Cite this article :}

Robertua, V., \& Silitonga, I. J. H. (2021). The Role of Media in The United States Environmental Diplomacy: A Case International Studies on Energy Affairs, 2(1), 30-53. https://doi.org/10.51413/jisea.Vol2.Iss 1.2021.30-53 


\section{INTRODUCTION}

Environmental problems such as water pollution, deforestation, and illegal hunting of animals are very alarming. The importance of solving these ecological problems has encouraged international community awareness and created a new form of diplomacy called environmental diplomacy. Environmental diplomacy is a tool to address environmental issues through diplomacy and the foreign policy of a country. Environmental diplomacy in the international sphere has several diverse meanings, according to several experts.

Pramudianto defined environmental diplomacy as the science and art of studying and dealing with environmental issues to achieve conformity with national interests (or the interests and policies of non-state entities), especially foreign policy and domestic politics in a country's ecological field (Pramudianto, 2011). Pramudianto explained that there is an essential component in the study of environmental diplomacy, which we can see from the institutional structure, processes, and plan carried out through environmental diplomacy. According to Forsyth, public concerns about environmental issues are significant because they show how ecological change experienced by them becomes a problem. They offer insight into the political processes that shape policy interventions. Social scientists refer to the relations between public awareness and policy challenges as "environmental narratives" because they formulate the concepts of blame, risk and potential solutions (Forsyth, 2014)

To obtain support from public opinion, one of the optimal tools used frequently is the mass media. According to Lang in (Severin \& Tankard Jr., 2008), "the mass media imposes specific issues. The mass media builds public images of political figures. The mass media continually presents objects that show what individuals should consider, know, and feel in society". (Severin \& Tankard Jr., 2008). Public opinion, branding, image, and reputation offer rich variations for policymakers in ensuring environmental protection throughout the world. Public relations lobbyists and consulting firms will survey news about specific environmental issues and suggest communication strategies to change perceptions about the government's reputation on environmental issues (Robertua, 2019). In short, the relation between environmental diplomacy and the media is about applying communication tools to shape people's perception of a country's policy or response in environmental matters. Environmental diplomacy aims to change the effectiveness of communication strategies in achieving reputation and image as an environmental actor.

In 2010, the world was shocked by a Deepwater Horizon disaster. The disaster also had a devastating impact on several vital aspects in the surrounding area, such as 
the economic, social, and, most importantly, environment. The Transocean offshore drilling contractor owned the Deepwater Horizon oil rig and leased it by the British Petroleum energy company. This rig is operated by Transocean, which works under BP as a company that holds rights and authority in carrying out oil drilling activities in one of its operational areas, the Prospect of Macondo. The Macondo prospect itself is a prospect of oil and natural gas located within the United States Exclusive Economic Zone (EEZ), precisely in the waters of the Gulf of Mexico.

On April 20, 2010, Deepwater Horizon reportedly approached the completion of an oil well when uncontrolled hydrocarbon gas (petroleum and natural gas) overflowed and caused an explosion. The accident resulted in $11 \mathrm{crew}$ members from the rig killed and the oil well leaking. United States federal government officials estimate that the well released more than 200 million gallons (or 4.9 million barrels) of crude oil to the surrounding sea level in more than 84 days. This case became the most massive maritime oil pollution case in history for the United States (Ramseur, 2010). The leak of oil that occurred due to drilling activities in this region had caused a detrimental impact on the surrounding environment. Widespread pollution caused by oil spills has affected the marine ecosystem, including marine biota and water quality along hundreds of miles of Gulf coastline.

This case also brings significant harm to the economy and livelihood of the local area, especially people who work as fishermen. The declining fish population due to the impact of pollution in these water areas has disrupted the community's welfare and harmed the whole fishing industry. Water that has been polluted by leaked oil also contains poisons harmful to public health and plants around the coastline. The losses incurred from this disaster have immediately attracted the attention of the international public. This attention results from the influence of media publications either through the news coverage of newspapers, radio, internet, television, and even film.

Related to the case study in this research, The United States, as a country that receives impacts from pollution and environmental damage in the case of Deepwater Horizon, demands compensation and accountability from BP. The US uses the Deepwater Horizon film as a 'blanket' to explain its environmental diplomacy. The US uses this environmental diplomacy covered by Hollywood drama to encompass public opinion and transform people's perceptions in support of the US position and raise its reputation in the public eye in this case.

The independence and objectivity of the reporting are the centre principles of media, which is never a straight-talking. Irregularities commonly shape the news that follows ideological orientations and the political-economic interests of the media. 
Meanwhile, the study of media content cannot be separated from the framework of interpretation that contains the concept of the public sphere (public space/area). The media occupies a central position that functions to supply and disseminate information needed for attitude determination, facilitate the formation of public opinion, and position itself as an independent forum where general issues can be debated (Sudibyo, 2001).

Three essential elements are the centre of this research, namely the media, environmental diplomacy, and the case of the Deepwater Horizon film. The researcher also used that the concept of environmental diplomacy could solve environmental damage and a reference to criticize the elements that caused the problem in this study.

\section{LITERATURE REVIEW AND STATEMENT OF ART}

In analyzing this research, the researcher found a connection and relevance from several previous types of research. Several previous kinds of research have similarities in their discussion about the role of the media in environmental issues and other international issues. Several studies discuss the Deepwater Horizon event and its impact using different perspectives, concepts, and sides.

Several studies also discuss applying the concept of environmental diplomacy in relations between countries and the role of the media in environmental issues and other international political activities. The researcher makes some of this as reference materials to assist the researcher in examining more deeply the problems presented in this research.

The researcher reviewed the first study as literature in this research is research with the title "Peran Film Sebagai Media Sosialisasi Lingkungan," written by Ahmad Toni. In this research, Toni analyzes the role of film as a tool that can influence individuals, groups, and other countries to instil ideology and realize interests.

Asian Development Bank (ADB), as an international lending institution, is an example of a subject that uses film with an environmental theme, especially in the availability of clean water with a specific purpose. The conclusion from Toni's research is that ADB uses film to trap capitalists in a socialist way. ADB seeks to instil the issue by standing on the social side as a form of marketing debt loan products to ensnare member countries using the product (Toni, 2015). From the description above, there are fundamental differences between the research written by the researcher with Toni's research. The researcher used a different case study that was not the same as Toni's research. The researcher used the Deepwater Horizon film as a study case that raised the oil rig incident in the Gulf of Mexico. 
The researcher does not focus on any international organizations or institutions that use film and other mass media as political objects to realize their interests. The researcher focuses on a specific state as a subject that uses mass media as a political tool in realizing its national interests. The country that the researcher referred was the United States. This country has experienced environmental and economic losses due to the Deepwater Horizon oil leak case caused by the British energy company, BP.

The result of the second literature reviewed by the researcher is a study entitled "Diplomasi Lingkungan Hidup Indonesia - Norwegia Melalui REDD+ Agreement," written by Pramesthi Cahyani Hedhi Ningsih. This research focuses on Indonesia's collaboration with Norway on environmental issues, specifically deforestation and land degradation. This research uses a qualitative method and looks at the process of environmental diplomacy carried out by Indonesia and Norway in implementing the REDD+ agreement, using six key elements of diplomacy (Ningsih, 2019). REDD+ is an international action program in reducing deforestation and forest degradation. REDD+ helped developing countries in financing and technology transfer in the implementation of sustainable forestry. Many countries have joined REDD+, including Indonesia. This research indicates that the Indonesia-Norway REDD+ cooperation has been going well, based on the national interests of the two countries. Even though REDD+ experienced a delay in achieving the target set for 2016 by Indonesia because Indonesia has not been able to meet the requirements provided by Norway to establish an institutional setup, Indonesia and Norway continue to work together to achieve the agreed targets until they are completed (Ningsih, 2019).

The differentiator elements between this research and Ningsih's are the objects that focus on both studies. The researcher was not focusing on the collaboration between the two countries in solving environmental problems like Ningsih. Although using the same concept, namely environmental diplomacy, the researcher was more focused on the basic ideas of the concept of environmental diplomacy and the role of the media in the concept application process, which are the necessary instruments in this research. The researcher uses these two instruments as units and analytical tools in answering research problems related to the use of media by the US in supporting its political practices on the issue of Deepwater Horizon environmental pollution.

The result of the third literature reviewed by the researcher is a study entitled "Environmental Diplomacy: Case Study of the EU-Indonesia Palm Oil Dispute," written by Verdinand Robertua. This research analyzes the dynamics of EU environmental diplomacy through a case study of the palm oil conflict between the 
European Union and Indonesia. Indonesia and Malaysia protested the European Union's decision to pull out palm oil as renewable energy in Renewable Energy Directive II. This decision happened because the expansion of the oil palm area had caused deforestation and forest damage. Through this case study, Robertua found that Indonesia's environmental diplomacy dynamics underwent three stages: a low carbon economy, a green leadership of the European Union, and an IndonesiaEuropean Union trade war (Robertua, 2019).

There are differences in the case studies taken in this study and in the researcher's research from the description above. This study also uses international actors, namely countries and regional organizations, as the main subject of the study. Simultaneously, the researcher focuses on the role of the media in US environmental diplomacy in a case study, the Deepwater Horizon film. Although using the same concept, the focus of the two studies is different. Another different example is the source that the researcher use. The researcher uses film as one of many forms of media that is popular today.

The fourth literature comes from a study entitled "Kebijakan Pemerintah Amerika Serikat Dalam Menangani Tumpahan Minyak British Petroleum Di Teluk Meksiko Periode 2010 - 2013," written by Muhammad Fadhli. In his research, Fadhli explained the analysis of the factors that influenced the United States government's policy in handling British Petroleum oil spill cases in the Gulf of Mexico from 2010 through 2013.

This study used a qualitative method with data collection techniques, like a literature survey. This study uses two concepts, namely national importance and civic environmentalism, as units of analysis. In this research, Fadhli concluded that US policies include the implementation of a moratorium on drilling in the Gulf of Mexico, the formation of organizations, the making of laws and programs as an effort to handle the case based on national interests and domestic and external environmental factors (Fadhli, 2014)

Although using the same case study, the difference between Fadhli's research and that this research is the concept used as a unit or analysis tool. The researcher uses the idea of environmental diplomacy as a unit of research analysis. The researcher also did not focus entirely on international actors such as the state in the case studies taken.

The fifth literature entitled "Environmental Documentary Film: A Contemporary Tool for Social Movement," written by Rachel Gregg, explained that in creating 21stcentury movement groups that can provide inspiration and social structural change, a persuasive and motivational new strategy is needed. The strategy is to use an 
environmental documentary. The environmental documentary can dramatize the reality of environmental issues and strengthen the audience to participate in the changes facing the ecological crisis. Gregg uses two environmental documentary films as examples in his research, and both films are titled Food Inc and Bag It (Gregg, 2011)

Both films, which used as instruments in Gregg's research, focused on environmental issues. Food Inc is a film that explains problems in the food system, while Bag It is a persuasive film that aims to create awareness in the audience to reduce plastic products. In this study, Gregg concluded that in this new 21st century, conventional rhetorical methods are no longer reliable for creating a social movement group. New creative, attractive, and educational strategies are necessary to promote environmental awareness of the community and society worldwide. One of the latest innovative approaches is using film. By using film as a new communication element, we can deliver rhetorical messages and create public awareness to protect the environment.

From the description above, there are fundamental differences from the research written by the researcher with Gregg's. First, the researcher does not thoroughly discuss the film as a medium for creating any social movement groups. The researcher analysed the use of film as one of the research instruments to explain how vital the role of the media is in international environmental politics, especially in environmental diplomacy conducted by the US. Second, the researcher only uses one film example, the Deepwater Horizon, as an object that represents and is related to the case study that the researcher used in this study. Moreover, the researcher used the concept of environmental diplomacy to explain media use in the film as a political tool of the United States in cornering BP in the Deepwater Horizon case.

The sixth literature review refers to a study entitled "The Politics of Accuracy in Judging Global Warming Films," written by Felicity Mellor. In this study, Mellor raised a controversial case in the UK in 2007. The case includes two documentaries on global warming, namely An Inconvenient Truth and The Great Global Warming Swindle, subject to legal and regulatory challenges in the UK. Mellor's research analyses the limitations of appealing the discourse of accuracy in both films. Mellor explains the discourse of accuracy used to see the accuracy of the facts and see the political elements contained in the two films cause problems (Mellor, 2009).

According to Mellor, the use of accuracy claims in assessing documentary films is inadequate and insufficient because the role of image visualization also needs to be considered. Mellor also explained that the use of the discourse of accuracy could expand the controversial problems and be a source of all kinds of political activities. 
Mellor argues that observing the textuality of documentary films can help evaluate the text's truth. We can see accuracy discourse as one of the many textual features compared to making the discourse of accuracy as private property (a kind of textual singularity that points only outward to the reference reality). These textual features will work together to build the integrity of the entire text, signifying honesty, openness, and honesty.

From the description above, several things distinguish the research written by the researcher and Mellor's. The researcher uses film as a form of media to explain the role of the media itself in international environmental politics, especially in US environmental diplomacy. The researcher also took a different film example, the Deepwater Horizon film. Deepwater Horizon is a film that tells the reality of the accident from the perspective of one of its workers. In analysing the use of this film as a tool for the US to carry out its environmental politics, the researcher used the concept of environmental diplomacy. An idea related to environmental issues and international environmental politics is also relevant to the case in this study.

In continuing several of the studies above, the researcher will raise research entitled "The Role of Media in US Environmental Diplomacy: A Case Study of Deepwater Horizon Film." The differentiation of the researcher's study and the several kinds of research above is the main focus of this research to prove the importance of the role of the media in international environmental politics and environmental issues, specifically environmental diplomacy conducted by the United States.

The researcher will use a specific film as a case study highlighting the accident of an oil drilling rig in the Gulf of Mexico in 2010, and the film is Deepwater Horizon. In the movie, the oil spill case that occurred in the Gulf of Mexico results from the explosion of a drilling rig managed by BP company. The concept that the researcher use is environmental diplomacy. This concept will assist the researcher in answering problems in this study.

\section{METHOD}

The researcher used qualitative research methods in this research. According to John Creswell, qualitative research is defined as an approach or search to explore and understand a central phenomenon (Raco, 2010). The researcher uses qualitative research to analyse the role of the media in international environmental politics, especially in US environmental diplomacy, by taking a case study of the Deepwater Horizon film.

The researcher also uses qualitative descriptive-analytic types. According to Sugiono, the descriptive method describes or gives an overview of the object studied 
through data or samples collected by concentrating research on the problem. The research results are then processed and analysed to conclude (Sugiyono, 2005).

This research will provide a detailed description of how much the role of the media concerning international environmental politics, particularly environmental diplomacy carried out by the United States. This study takes the Deepwater Horizon movie to describe the magnitude and importance of media capacity in influencing environmental diplomacy related to the case. This type of descriptive research is relevant to the title of this study because it focuses on analysing the concept of environmental diplomacy in providing solutions to environmental problems contained in this study.

The researcher made observations through the Deepwater Horizon film directed by Peter Berg, released in 2016. Data collection techniques include 2 (two) methods: (1) Observation by observing objects relevant to the research. (2) Documentation, by analyzing the data available from various sources such as reports, news, pictures, or schematics.

The researcher used qualitative research, where there are validity and reliability data tests through the "Triangulation" technique. Triangulation divided into five techniques, namely: triangulation of sources, theory triangulation; triangulation of researchers; time triangulation; and triangulation of methods. In this research, the researcher used source triangulation techniques. According to Patton, the triangulation of sources means comparing and double-checking the degree of trust in information obtained through different sources. The researcher compared the results of observations with documents obtained in books, scientific journals, and information from the mass media (Moleong, 1999).

In this study, the researcher will collect data from various sources. These sources include some expert perspectives related to the problems in this study, documents, and reports from the mass media and journals officially published by government and non-government. The researcher will compare the collected sources to find the actual and concrete bases to use as data in this research.

Data analysis in research is solved in three ways: data reduction, data presentation, and drawing conclusions or verification. First, data reduction is the process of data analysis to reduce and then summarize the fundamental research. It is helpful to facilitate data understanding into a more detailed reference. Second, the data presentation solved in the form of a report following the research results obtained. Third, verification is giving meaning to research conducted or analyzed. 
This process begins with structuring field data and reduces it to unification in the form of data categorization. In this research, the researcher will use data reduction methods. The researcher will collect the data obtained and summarize it according to its relevance in this research. The researcher does this to look for equivalent and related data to be categorized in the same type.

\section{RESULT AND DISCUSSION}

\section{The Impact of Oil Spills on the Environment around the Gulf of Mexico}

Deepwater Horizon is an oil drilling rig owned and operated by the offshore oil drilling company Transocean and leased by the oil company BP. This rig is in the Mississippi Canyon, a valley on a continental shelf to obtain oil from the Macondo Prospect in the Gulf of Mexico. The oil well located on the seabed, 4,993 feet (1,522 meters) below the surface (Pallardy, 2020).

On the night of April 20, a wave of natural gas exploded through a concrete core that had just been installed by a contractor Halliburton. BP used this core to seal the well so that it becomes reusable until the drilling sequence. Halliburton itself is one of the best oilfield service provider companies in North America that provides cementing services for BP in Macondo wells, including the placement of "centralization," which helps stabilize the wellbore during cementing (Rushe, 2014).

The concrete core installed by Halliburton may be too weak to withstand the pressure because it consists of a concrete mixture that uses nitrogen gas to speed up the curing process. After being released by a core fracture, the natural gas climbed onto the rig, exploded, killed 11 workers, and injured 17 people. The Deepwater Horizon rig capsized and sank on the morning of April 22 and broke the riser, a large diameter pipe connecting the underwater BOP (Blowout Preventer) stack to the surface of the rig used to bring mud back to the surface (Schlumberger). Without a riser, mud will only spill from the top of the pile to the seabed. The absence of opposing forces causes oil to begin to flow into the bay. (Pallardy, 2020).

United States federal government officials estimate that the well released more than 200 million gallons of crude oil to sea level in more than 84 days. This case is the most massive maritime oil pollution case in US history (Ramseur, 2010). Oil leaks that occur due to drilling activities in this region are very detrimental to the surrounding environment. Widespread pollution caused by the oil spills has affected the marine ecosystem, including marine biota and water quality along hundreds of miles of Gulf coastline. The oil leak also caused social and economic 
impacts on the surrounding communities. Nearby industries, such as tourism and fisheries, also receive losses on a large scale.

The environmental impact caused by the fire incident of the Deepwater Horizon rig was immense. Oil leaks that last for approximately 84 days have caused high-scale and long-term environmental pollution. The Deepwater Horizon rig oil spill has endangered organisms that inhabit the oceans and coastal areas in the Gulf of Mexico. Coastal areas are the most vulnerable areas because waves and tides wash away stranded oil in wetlands such as swamps, rivers, and lakes. The absorption of dissolved oil components is toxic to fish, shellfish, invertebrates, and plankton. Oil can also cover small animals and plants that live in the area around the coastline and make them suffocate (Upton, 2011).

Commonly found species in the bay area and the surrounding natural environment are seabirds such as brown pelicans, sea ducks, different types of fish and marine mammals, oysters, crabs, shrimp, turtles, and native flora and fauna as a result of changes in the chemical composition of water (habitat) and the palpable shift in habitat gradually (Neff, 2002). We can see the effects of oil spills in the Gulf of Mexico on living things in the ecosystem. As seen in picture 3.2, living things covered in oil will have trouble breathing due to exposure to the toxic effects of the oil. The oil that protects the fur or animal skin will destroy the insulation value of these living creatures and cause them to die from hypothermia (Mansir \& Jones, 2012).

According to a report from an environmental NGO from the United States, the Centre for Biological Diversity, it was found that oil spills may have injured or killed around 82,000 birds from 102 species, around 6,165 sea turtles, up to 25,900 marine mammals, including several species of dolphins and whales. The oil spill also injured several fish, including bluefin tuna and substantial habitat for the smallest seahorse in the United States. The spill also covers more than a thousand miles of coastline, including beaches and swamps, where the most prominent victims are animals and plants found on the shoreline, namely seagrasses, shorebirds, and other living creatures (Center for Biological Diversity, 2011)

The effects of oil spills caused by accident on the Deepwater Horizon drilling rig have not even ended in a decade. Until now, the long-term effects of these events are still visible and unresolved. Researchers can not accurately calculate the quantity of the oil that pollutes the waters of the Gulf of Mexico because the oil expands and settles below sea level. This oil spill also affected three coastal regions of the United States of America, namely Alabama, Mississippi, and Louisiana. 
Immediately after the oil spill occurred, 1,300 miles of contaminated coastal areas experienced 100 times higher oil concentrations. Even eight years later, the intensity was ten times higher than before the spill. In February 2020, a study showed that the oil footprint spread about 30 per cent more extensive than previously estimated, potentially contaminating more fish populations than previously thought. Scientists are still figuring out exactly how oil impacts the physiological state of the Gulf of Mexico. Nevertheless, according to a study, the immediate effect is to change the seabed near an oil well into a "toxic waste disposal site" (Borunda, 2020).

In addition to having a profound impact on the Gulf of Mexico's physiological state and environmental ecosystems, the Deepwater Horizon oil spill also impacts the social and economic life of the people who live around it. Communities living in coastal areas generally work as fishermen, fish farmers, or other work related to the fishing industry. Communities living in coastal regions also utilize the beach area as a centre for tourism to attract tourists from outside their area. Using these two industries, people in coastal areas can maintain their survival and economy so they can be stable.

As a result of oil spills covering the waters of the Gulf of Mexico, both industries received very significant damage. Environmental pollution that occurs at sea brings a direct impact on the socio-economic sector of the area. Most federal territorial waters that receive immediate and adjacent effects are immediately closed after the oil spill is unstoppable. On June 2, 2010, the federal waters were closed to fishing activities had expanded to reach 88,522 square miles or nearly $37 \%$ of federal waters in the Gulf of Mexico. The top portion of state waters closed for fishing activities are as follows, Alabama (40\%), Florida (2\%), Louisiana (55\%), and Mississippi (95\%) (Upton, 2011).

Closure of the Gulf of Mexico waters has led to a decline in commercial fishers' productivity in the area. This closure becomes the prevention of the entry of seafood products that have the risk of being contaminated with oil spills on the market. Areas affected by the shutdown are some of the most affluent fishing areas in the Gulf of Mexico. This area is a habitat for commercial species such as shrimp, menhaden fish, and oysters. Compared to the same period in 2009 (January to December), the total catch in the Gulf for shrimp species in 2010 decreased by about 35.6 million pounds (27\%) at the state level, $32 \%$ in Louisiana, 60\% in Mississippi, $56 \%$ in Alabama and almost $15 \%$ in Texas. Menhaden fishing in Louisiana also declined 171 million pounds, or about $17 \%$ (Upton, 2011). According to a new study by the US Bureau of Marine Energy Management, the Gulf of Mexico commercial fishing industry losses costs $\$ 94.7$ million to $\$ 1.6$ billion. These losses also include 
the loss of 740 to 9,315 jobs in the first eight months after the disaster (Schleifstein, 2016). These losses caused a decrease in the catch of commercial fishers operating in the bay area. The closure of fishing areas also causes the fishing industry to suffer injuries that forced them to impose terms of employment on a large scale. The loss of the opportunity to make a living is a bitter dilemma for local people. Their welfare to live in the area has become disturbed. This disaster is a common enemy that becomes a consideration for preventing losses that could be next.

\section{Ethnographic Content Analysis (ECA)}

Various types of content analysis are used to analyse the content and problems in the media. These types of studies used for research methods that focus on the newspaper media as a lens in looking at issues in political discourse, social issues, religion, conflict, pluralism, and many more. Burhan Bungin, in the book entitled "Metodologi Penelitian Kualitatif," explains that qualitative media content analysis more widely used in examining documents in the form of text, images, symbols, and others. To understand the culture of a particular social context (Bungin, 2001), this type of analysis also applies to analyse increasingly evolving audio-visual texts such as television and film.

Bungin also explained that the document in qualitative content analysis is a form of symbolic representation that can be recorded or documented as a content analysis method in understanding its meaning, significance, and relevance. David L. Altheide prefers to use the term Ethnographic Content Analysis (ECA) to explain the research model of qualitative content analysis.

The term ECA is a combination of the traditional notion of objective content analysis with participants. According to Altheide, in-depth ECA is used to document and understand the communication of meaning and verify the theoretical relationship. Its distinctive characteristics are the intuitive and highly interactive nature of sympathizers, concepts, data collection, and analysis (Altheide \& Schneider, 2013).

While Kriyantono considered that in ECA, researchers who interacted with documentation materials were able to conduct in-depth interviews to get the context (Kriyantono, 2008), the content analysis depends on some categorical data or documentation validation. These categories include war, defence and diplomacy, politics and government, economic activity, crime, public moral issues, health and welfare, accidents and disasters, science and inventions, education and classical arts, folk entertainment, and human interest (Flournoy, 2000). These categories are part of the categorization process that results in the birth of perspective or the way someone sees an event. This idea called framing. Edelman states that framing 
results from the categorization process carried out by the human mind on various events they experience. With categorization, we can understand a fact or reality when using a particular perspective. Furthermore, the categorization process requires the use of certain words to realize the facts or truth.

Besides, categories help people understand the diverse and irregular reality into a reality that has meaning. According to Edelman, we can use categorization to simplify complex and multidimensional realities by emphasizing precise dimensions and leaving other aspects of observation. Therefore, Edelman aligns the classification with the framing process (Rohmatullah, 2017). The media often use framing to influence people's perspectives. The public is not aware that their realms of mind and consciousness dictate a particular aspect, so they do not think in other dimensions. Ibnu Hamad, in the book entitled "Komunikasi Sebagai Wacana," states that certain factors influence the construction of reality. These factors include innocently, internality, and externality.

Certain parties often use language to arrange facts (Hamad, 2010). This idea's name is framing manipulation. Kriyantono explained in the ECA; researchers faced several issues concerning systematic content analysis as a guide to categorizing (Kriyantono, 2008), including:

\section{A. Content}

B. Process (packaging media forms)

C. Emergency, which is the stage of the gradual formation of a message through interpretation.

Furthermore, Bungin also stated that any type of image text, including moving images (movies), must pay attention to several things (Bungin, 2001), including:

A. Studied context or social situation around the document or text.

B. Process, media production, or content in messages are created and organized.

C. Emergency, the meaning of a message is conveyed through its understanding and interpretation.

To understand the meaning of the Deepwater Horizon film, the researcher used two aspects: narrative and cinematic. The researcher uses both of these aspects as a means of interpretation and analysis in understanding the purposes of the film and point of view (framing) formed by the director, Peter Berg. 
The Deepwater Horizon is a film formed to reconstruct the Deepwater Horizon fire event from Mike Williams's perspective. The director designed the movie as realistic as possible to raise public awareness of the struggle of Transocean workers in defending their lives from the disaster. The film focuses on Mike's life with his family and his work as chief engineer at the Deepwater Horizon drilling rig. This film combines several aspects of the genre, such as drama, disaster, survival, and minor heroic elements.

The researcher regards this film as a subjective film. Although showing different aspects and terms that describe exploration and exploitation in the oil and gas industry, this film is very focused on the main protagonist. It oversimplifies the facts that occur in the field. The first simplification of points is the party responsible for the Deepwater Horizon case. In this film, BP is portrayed as greedy people where they are the cause of the accident. However, the facts state that BP is not the only partly responsible for the incident. The other parties were Transocean and Halliburton's nursery contractor, who were negligent in carrying out their obligations.

The second simplification of facts is about the cause of the accident that can occur. The Deepwater Horizon movie explained that Vidrine, a BP official, made a wrong decision that resulted in the overflow of mud and oil to the rig's surface. The mud and oil overflow ignited a fire accompanied by an explosion in the machines at the rig's body. On the other hand, the facts are far more complicated than those shown in the film. The fact states that the explosion was not the result of a single wrong decision but from a series of events that allowed the 'barrier' that intended to prevent the disaster from becoming malfunctioning (Oort, 2016).

It is also clear that in this film, the director is very much in favour of Transocean. This partisanship, shown through various debates, strongly cornered BP as the most negligent party. All the actions and dialogues of Mike Williams also played well by Mark Wahlberg, which seemed to justify that he was 'the hero,' and Transocean was the right people.

The director very well-formed this framing. The moral message contained in it is also neatly packaged. Dramatization that occurs in some scenes of this film shows that there are political elements that the director tries to insert. These political elements are undoubtedly related to the Deepwater Horizon oil spill case, which used as a tool in leading public opinion. 


\section{The US Environmental Diplomacy}

Most Hollywood films made for commercial purposes as they are released to gain financial income for the production house and the filmmakers. Although the function of the film is to entertain the audience, specific groups or individuals use many films to fulfil their political interests. Some famous Hollywood films have political elements that hidden and inserted in the movie. The political factors dramatized in such a way that the audience can be influenced and more easily manipulated. Dramatization that occurs usually done by using a gimmick as a cover in covering political elements.

The dramatizations and gimmicks used to have strong links with a genre in a movie. One example is the film Iron Man. Iron Man is a film that tells the life of a wealthy billionaire from the United States with a high intellectual level. He used his abilities and resources to make himself a hero. The film Iron Man uses the 'hero' as a gimmick to attract the audience's attention. After the gimmick has successfully influenced the audience, the dramatization process will be present. The dramatization that came included the protagonist's personal story and his struggle to save ordinary people from criminals. If examined in depth, there are political elements hidden in the film Iron Man. One political component of the film is the portrayal of the superiority of the United States as a superpower that has abundant resources and advanced technology.

We can also see political elements in the Deepwater Horizon film. In the beginning, the film invited the audience to focus on the main character, Mike Williams. The audience sees the simple life of Mike, who began to interact with his family and coworkers. Then the film underwent a transition and showed the conflict between Transocean, represented by Jimmy Harrel and Mike Williams with BP, represented by Donald Vidrine and Robert Kaluza. The conflict presented by the filmmakers shows that $\mathrm{BP}$ is the antagonist responsible for the accidents and disasters that occur on the rig.

Framing in this film is made to influence the audience's perception to side with the main protagonist and create a sense of sympathy in the audience's mind for Transocean employees who died in the accident. The gimmick used in the Deepwater Horizon film focuses on the fire and explosion on the rig. After the scheme in the movie is successful, the dramatization will be present to manipulate the feelings of the audience. One example of the dramatization in the Deepwater Horizon film is a scene that shows the efforts of the Transocean crew to survive the disaster. Another example is the heroic moments of the main character that tries to save his friends and co-workers from the fire. 
We can also see certain political elements in the Deepwater Horizon film when the film concludes. The director reaffirmed his alignments with Transocean and cornered BP by presenting the facts of the case. These facts include the legal verdicts, the impact of the incident, and the list of employees who died due to the burning of the Deepwater Horizon drilling rig. If related to several aspects of IR, such as politics, economics, and the international environment, this film is used by the US as a political tool in implementing environmental diplomacy. Through this film, environmental diplomacy conducted by the US aims to solve various problems such as water pollution, damage to ecosystems, and economic impacts that occur in the area around the Gulf of Mexico.

The contextualization of this film as a tool of US politics utilized in two ways:

\section{A. As a Tool to Support US Political Schemes}

The US conducted and used Environmental Diplomacy to corner BP in the public eye through the Deepwater Horizon film. BP's declining image will force it to remain accountable by paying compensation to the government and affected communities and helping finance government research and environmental NGOs to implement environmental restoration in the Gulf of Mexico. This film also used to support the political scheme used by the Obama administration to corner BP. One political scheme created by the Obama administration indirectly is political rhetoric, namely "anti-British" sentiment.

This sentiment itself formed from the name "British Petroleum," which was used by Obama administration officials when criticizing the company, sparking controversy in Britain. The US Ambassador to the United Kingdom, Louis Susman, said that Obama might have used the term "British Petroleum" once and subsequently used the designation "BP." Obama issued a statement in which he would fire BP's top executive, Tony Hayward, if proven responsible for the company and support the idea that they postpone quarterly dividends to shareholders (BBC News, 2010).

This comment sparked outrage among business workers and retirees in the UK who invested in BP. The statement issued by the Obama administration was considered inappropriate in reviewing the case. BP itself is a company that has changed its name several times since it entered into a merger with several other companies. The term "British Petroleum" is one of the names used by the company. The use of the name "BP" itself is a transition from British Petroleum in 1998. However, some parties in the Obama administration have clarified and stated that the Deepwater Horizon case has no relation to nationalism; this anti-British rhetoric was used indirectly to show the Obama administration's firmness public. 


\section{B. Manipulating the public by appointing BP as the sole actor in Deepwater Horizon}

The US government uses the framing contained in Deepwater Horizon movie content to influence the audience's mindset. The range of influence of this film is undoubtedly vast, considering this film is a Hollywood film that has circulated in many countries. We use the audience mindset that has been manipulated by this film suppress BP's position by making BP the sole actor to be criticized in the Deepwater Horizon case compared to US contractors such as Halliburton (Wintour, Macalister, \& Tremlett, 2010). This manipulation method is the same as the dramaturgy analysis used by Carolyn M. Hendriks in her study of the use of politics in social media.

The dimensions of the dramaturgical analysis proposed by Hendriks review political use in the social media centre on two things: scripting and staging. Scripting functions to create specific political effects by displaying characters in a show and directing them to behave as expected. While staging can organize, manage, and lead the material and audience to ensure that the show is "successful" (Hendriks, Duus, \& Ercan, 2016). Dramaturgy, built by the US, focuses on the Deepwater Horizon case as the narrative centre. The US then appoints several actors to portray the main character in the show it makes, with BP as the sole antagonist actor.

After the scripting of the dramaturgy formed, the US created a stage where he placed himself as an orchestrator. This analysis is one of the glasses used to interpret the use of the media in carrying out political interests. On the other hand, the US also uses the film Deepwater Horizon to encourage social movements to support its political scheme. This utilization is the same as the meaning of media by Bennet. $T$ internet and social media can change the political game that supports resource-poor players such as non-institutional actors, including those in the environmental movement (Hodges \& Stocking, 2016). Through these two analyses, the researcher argues that the US uses film as a tool to achieve its political interests in the Deepwater Horizon case. 


\section{CONCLUSIONS}

The Deepwater Horizon oil spill is a major disaster that has brought detrimental impacts to the United States. The accident has affected various aspects such as environmental, social, and economics. The losses suffered by the US make this environmental pollution problem became a political issue. This argument exists because the accident has taken away the state's national interest and the welfare of its people. To receive compensation, the US government, under the leadership of Barrack Obama, runs a variety of necessary political practices and schemes; one of them is environmental diplomacy. An environmental diplomacy is a new form of diplomacy used to solve various environmental issues and other related issues.

To support this political scheme, the US uses various forms of modern mass media as its political tool in cornering BP as the party most responsible for the oil spill in the Gulf of Mexico. One of the contemporary mass media that we use is film. The film is a viral media and easy to attract public interest. Through cinema, public perception of a matter can be manipulated and controlled in such a way by providing political elements that veiled in the film's content. The film used by the US as a political tool is Deepwater Horizon, a film directed by Peter Berg that tries to reconstruct the events behind the oil spill in the waters of the Gulf of Mexico.

The story in Deepwater Horizon movie came from a Transocean employee, Mike Williams, who explains how the Deepwater Horizon oil drilling rig caught fire and destroyed, causing oil spills to flow into the sea. The film illustrates that BP is the antagonist and the sole actor, destroying the Deepwater Horizon rig. Through this film, we can find that there are some political elements that the director tried to insert in the movie so it can manipulate public perceptions about BP. To not be seen clearly, the director uses Hollywood gimmicks and dramatization as a "blanket" to package the film neater and engaging for the public to see.

The film successfully circulated and attracted public attention both in its own country and in other countries worldwide. The success of this film dramatically benefits the US's position in carrying out its environmental diplomacy and other political schemes to corner BP. This success is proven by BP's image, which is getting worse in the eyes of the international public day by day. BP has no choice but to work together with the US government to implement environmental restoration and pay total compensation for its negligence. Through this description, the researcher concluded that the role of the media is vital in a variety of political activities, especially environmental diplomacy. The existence of the media in influencing the public becomes an essential essence for the US in the success of its environmental diplomacy practices. It is because people are the deciding factor, which is the biggest weapon in political activity. 
Environmental issues, especially seawater pollution in the Gulf of Mexico, are a joint issue that all parties must handle. This including non-state actors that move in environmental, social, or economic issues. This issue can threaten not only human health but also animals, plants, and other living things that surround the area. This joint issue should be dealt with periodically by carrying out environmental restoration, socialization, and intensive supervision. The level of pollution in maritime water in the region can continue to decrease.

The issues raised in the Deepwater Horizon film are not just political tools aimed at cornering BP alone. It is also a form of warning to provide awareness about humanity and the environment. Today's film industry also needs to have moral impacts on the public, who are the audience of films. So they don't just become political instruments. Still, they can transform into new societies with advanced and moral thinking power. Today's political activities, especially those related to environmental issues, need to adapt to modern mass media, popular among all people's classes and groups. The process of adapting political practices with contemporary mass media must be harmonious to produce a political product accepted by society. Political products approved by the community will become a face and increase the image of political individuals or a particular political group. 


\section{REFERENCES}

Ali, S. \& Vladich, H. V. 2016. "Enviromental Diplomacy." The SAGE Handbook of Diplomacy, 601-616.

Altheide, D. L. \& Schneider, C. J. 2013. Qualitative Media Analysis. London: SAGE.

Andrianti, N. 2015. "Peran Media Massa Nasional Dalam Politik Internasional." INFORMASI : Kajian Ilmu Komunikasi, vol. 45, no. 1, 43-56.

BBC News. June 13 2010. "BP oil spill: Obama comments 'not anti-British'." accessed on May 11 2020, from BBC News: https://www.bbc.com/news/10303619

Borunda, A. April 20 2020. "BP Oil Spill, Still don't know effects decade later." accessed on May 3 2020, from National Geographic: https://www.nationalgeographic.com/science/2020/04/bp-oil-spillstill-dont-know-effects-decade-later/

Bungin, B. 2001. Metodologi Penelitian Kualitatif. Jakarta: Radja Grafindo Persada.

Center for Biological Diversity. 2011. "A Deadly Toll: The Gulf Oil Spill and the Unfolding Wildlife Disaster."

Fadhli, M. 2014. "Kebijakan Pemerintah Amerika Serikat Dalam Menangani Tumpahan Minyak British Petroleum di Teluk Meksiko Periode 2010 2013.", 1 - 120.

Flournoy, D. M. 2000. Analisis Isi Surat Kabar Indonesia. Yogyakarta: Gadjah Mada University Press.

Forsyth, T. 2014. "Public concerns on transboundary haze: a comparison of Indonesia, Singapore and Malaysia." Global Environmental Change, 7686.

Gregg, R. 2011. "Enviromental Documentary Film : A Contemporary Tool For Social Movement.", 1-92.

Hamad, I. 2010. Komunikasi Sebagai Wacana. Jakarta: La Tofi Enterprise.

Hendriks, C. M., Duus, S., \& Ercan, S. A. 2016. "Performing politics on social media: The dramaturgy of an enviromental controversy on Facebook." Enviromental Politics, vol. 25, no. 6, 1102-1125. 
Hodges, H. E., \& Stocking, G. 2016. "A pipeline of tweets: environmental movements' use of Twitter in response to the Keystone XL pipeline." Enviromental Politics, vol. 25, no. 2, 223-247.

Kriyantono, R. 2008. Teknik Praktis Riset Komunikasi. Jakarta: Kencana Prenada Media Grup.

Mansir, N., \& Jones, M. 2012. "Enviromental Impacts of Marine Oil Spill; A Case Study of Deepwater Horizon Oil Spill at the Gulf of Mexico United State of America 2010 (A Review)." Chemsearch Journal 3(2), 64-70.

Mellor, F. 2009. "The Politics of Accuracy in Judging Global Warming Films." Enviromental Communication, vol. 3, no. 2, 134-150.

Moleong, L. J. 1999. Metodologi Penelitian Kualitatif. Bandung: Remaja Rosdakarya.

Mudjiono, Y. 2011. “Kajian Semiotika Dalam Film.” Jurnal Ilmu Komunikasi, vol. 1, no.1, 125-138.

Neff, J. 2002. Bioaccumulation in Marine Organisms: Effect of Contaminants from Oil Well Produced Water. Elsevier.

Ningsih, P. C. 2019. "Diplomasi Lingkungan Hidup Indonesia-Norwegia Melalui REDD+ Agreement.” Insignia Journal of International Relations, vol. 6, no. $2,83-93$.

Nugroho, H. 2001. Produksi Film. Jakarta: Grasindo.

Oort, E. V. October 8 2016. "Deepwater Horizon Honors Oil Rig Workers But Oversimplifies The Blowout". accessed on May 6 2020, from The Conversation: https://theconversation.com/deepwater-horizon-honorsoil-rig-workers-but-oversimplifies-the-blowout-66391

Pallardy, R. March 13 2020. Deepwater Horizon oil spill. accessed on March 24 2020, from ENCYCLOPÆDIA BRITANNICA: https://www.britannica.com/event/Deepwater-Horizon-oil-spill

Pramudianto, A. 2011. Diplomasi Lingkungan. Jakarta: Universitas Indonesia Press.

Prasetyo, A. 2011. Buku Putih Produksi Film Pendek: Bikin Film Itu Gampang. Tegal: Bengkel Sinema. 
Pratista, H. 2008. Memahami Film. Yogyakarta: Homerian Pustaka Widiasarana.

Raco, J. 2010. Metode Penelitian Kualitatif : Jenis, Karakteristik dan Keunggulannya. Jakarta: Gramedia.

Ramseur, J. L. 2010. "Deepwater Horizon Oil Spill: The Fate of The Oil". Diane Publishing.

Robertua, V. 2019. "Enviromental Diplomacy: Case Study Of The EU-Indonesia Palm Oil Dispute." Mandala : Jurnal Hubungan Internasional, vol. 2, no. $1,1-21$.

Rohmatullah, A. 2017. "Analisis Framing Murray Edelman dalam Periwayatan Hadith Bi Al-Ma'Na." Islamika Inside : Jurnal Keislaman dan Humanoria, vol. 3, no. 2, 243-264.

Rushe, D. September 2 2014. Halliburton reaches $\$ 1.1 b n$ settlement over the Deepwater Horizon oil spill. accessed on May 12020 , from The Guardian: https://www.theguardian.com/environment/2014/sep/02/halliburton11bn-settlement-deepwater-horizon-spill

Schleifstein, M. June 27 2016. BP Oil Spill Cost Fishing Industry at Least \$94.7 Million in 2010. accessed on May 4 2020, from Nola.com: https://www.nola.com/news/environment/article 462806af-c1e5-57129608-31b125c43c8c.html

Schlumberger. Oilfield Glossary. accessed on May 1 2020, from Schlumberger: https://www.glossary.oilfield.slb.com/Terms/d/drilling_riser.aspx

Severin, W. J., \& Tankard Jr., J. W. 2008. Teori Komunikasi, Sejarah, Metode Dan Terapan Di Dalam Media Massa. Jakarta: Kencana Prenada Media Grup.

Siregar, A. 2000. "Media Pers dan Negara : Keluar dari Hegemoni." Jurnal Ilmu Sosial dan Politik Universitas Gajah Mada, vol. 4, No. 2, 171-196.

Sudibyo, A. 2001. Politik Media dan Pertarungan Wacana. Yogyakarta: LKiS.

Sugiyono. 2005. Memahami Penelitian Kualitatif. Bandung: Alfabeta.

Sumarno, M. 1996. Dasar Dasar Apresiasi Film. Jakarta: PT Gramedia

Toni, A. 2015. "Peran Film Sebagai Media Sosialisasi Lingkungan." Jurnal Komunikator, vol : 7, no : 1, 41-51. 

JISEA Robertua \& Silitonga | The Role of Media in The United States Environmental
Diplomacy: A Case Study of Oil-spill Disaster in Deepwater Horizon |

Upton, H. F. 2011. "The Deepwater Horizon Oil Spill and The Gulf of Mexico Fishing Industry". Congressional Research Service.

Wintour, P., and others. June 11 2010. BP oil spill: David Cameron caught between Tory right and Obama. Accessed on May 11 2020, from The Guardian: 